https://nv.nltu.edu.ua

\title{
ШЛЯХИ АКТИВІЗАЦІЇ БАНКІВСЬКОГО ІНВЕСТИЦІЙНОГО КРЕДИТУВАННЯ РЕАЛЬНОГО СЕКТОРУ ЕКОНОМІКИ
}

\begin{abstract}
Досліджено теоретико-методологічні та структурні особливості сутності банківського інвестиційного кредитування, яке об'єднує в собі поняття інвестицій і кредиту. Встановлено, що участь банків в інвестиційному процесі передбачає надання кредитів інвестиційного характеру на довготривалий період, а також вкладення коштів у цінні папери, паї, пайові участі як за рахунок банку, так і за дорученням клієнта. За результатами дослідження сутності банківського інвестиційного кредитування як довготермінової послуги своїм кредиторам, що бажають не просто розвивати свій бізнес, але які мають різні ідеї 3 удосконалення або відкриття нового напряму у своїй господарській діяльності, виділено принципи організації інвестиційного кредитування банком. Вивчено процедуру надання інвестиційного кредиту, яка склалася на практиці вітчизняних банків, що дало змогу встановити відповідність стадій кредитного процесу стадіям життєвого циклу інвестиційного проекту. Охарактеризовано перспективність венчурного фінансування високоризикових інноваційних проектів як щодо охоплення усіх стадій інноваційного циклу, так і щодо можливості акумуляції венчурного капіталу за рахунок різних джерел, зокрема, доходів від приватизації, ресурсів банків, засобів різних фондів, нерезидентів. Доведено гіпотезу, що банківські інвестиційні кредити, з одного боку, є обов'язковою фінансовою складовою в інноваційному процесі, а з іншого боку, кредитування інвестицій без інновацій, іпотечне кредитування, кредитування на розвиток бізнесу можуть сприяти посиленню потреби підприємств у розробці та впровадженні нововведень, які будуть створювати умови для залучення висококваліфікованих науково-технічних кадрів (сприяти інноваціям). Вдосконалено систему надання та погашення банківського інвестиційного кредитування реального сектору економіки, яке повинне включати два взаємопов'язані аспекти: оцінку інвестиційної кредитоспроможності, а також механізм визначення рівня процентної ставки за інвестиційним кредитом.
\end{abstract}

Ключові слова: інвестиції; банківський інвестиційний кредит; інвестиційний проект; інновації.

Вступ. Банківська система відіграє основну роль в акумулюванні інвестицій і їх перерозподілі між галузями народного господарства, а також у залученні коштів від реальних і потенційних вітчизняних та зарубіжних інвесторів. Сучасна банківська система $є$ одним з головних партнерів держави 3 реалізації грошово-кредитної та інвестиційної політики, оптимізації витрат і розподілу ризиків між суб'єктами економіки.

Діяльність комерційних банків значною мірою визначає економічну i соціальну стабільність у країні, можливість реалізації інтересів залучених у неї соціальних груп, рівень і якість життя окремої людини. Для подальшого збільшення обсягів кредитування, що направляються на відновлення i розширення пріоритетних напрямів структурних перетворень в економіці, модернізацію, технічне і технологічне оновлення виробництва, комерційні банки сьогодні проводять капіталізацію, збільшують обсяги залучення депозитних вкладів. Разом із розвитком ресурсної бази вдосконалюється інструментарій кредитування, форми і методи підвищення ефективності обслуговування клієнтів, впроваджуються сучасні технології і програмне забезпечення 3 моніторингу і управління кредитно-інвестиційним пор- тфелем, проводиться своєчасне оцінювання і управління ризиками.

Керівництво нашої країни неодноразово підкреслювало роль комерційних банків у реалізації структурних реформ і фінансування розвитку реального сектору економіки. Головними залишилися питання щодо розвитку та реформування банківської системи. Сьогодні істотно розширюється і зміцнюється ресурсна база банків, поліпшується якість надаваних ними послуг, знижується рівень облікової ставки. Сукупний обсяг кредитів, виданих реальному сектору економіки в 2020 р., має зрости на $30 \%$.

Актуальність теми дослідження визначається необхідністю подальшого вдосконалення системи заходів, спрямованих на збільшення обсягу інвестиційного кредитування комерційними банками проектів у реальному секторі економіки, спрямованих на проведення модернізації, впровадження сучасних технологій, створення нових видів наукомістких галузей промисловості [13].

Потреба української економіки в інвестиціях така велика, що пропозиція на ринку кредитування банками окремих галузей поки ще відстає від попиту, а питання довготермінового кредитування 3 боку комерційних

Інформація про авторів:

Сидоренко Віктор Анатолійович, канд. екон. наук, доцент, кафедра банківської справи.

Email: varenykva@ukr.net; https://orcid.org/0000-0002-8465-9982

Цитування за ДСтУ: Сидоренко В. А. Шляхи активізації банківського інвестиційного кредитування реального сектору економіки. Науковий вісник НлтУ України. 2020, т. 30, № 1. С. 104-108.

Citation APA: Sydorenko, V. A. (2020). Ways of activization the bank investment crediting for the real economy. Scientific Bulletin of UNFU, 30(1), 104-108. https://doi.org/10.36930/40300118 
банків у наукомісткі галузі реального сектору економіки загалом залишаються не з'ясованими. Тому основним завданням цього дослідження є вдосконалення наявних та розроблення нових шляхів розвитку банківського інвестиційного кредитування реального сектору економіки України.

Аналіз останніх досліджень та публікацій. Дослідження теоретико-методологічних основ інвестиційного кредитування, а також напрямів його активізації в галузі реального сектору економіки здійснено у працях вітчизняних науковців: Т. Васильєвої, О. Вовчак, І. Гуцала, В. Гейця, О. Дзюблюка, М. Єрмоленко, А. Даниленка, Л. Кльоби, В. Корнєєва, М. Крупки, І. Лютого, Т. Майорової, О. Мороза, А. Пересади, Б. Пшика, М. Савлука та ін. Значний науковий внесок із досліджуваної проблематики зробити також зарубіжні вчені, зокрема: I. Балабанов, Г. Бірман, В. Бочаров, С. Брігхем, Л. Гітман, Р. Кінг, О. Лаврушин, І. Ларіонова, Ю. Масленченков, Г. Панова, У. Шарп, С. Шмідт, Й. Шумпетер та ін.

Так, О. Д. Вовчак вважає, що інвестиційний кредит - це кредит в основний капітал $з$ метою розширення виробництва, що надається комерційними банками для здійснення ними інвестиційних вкладень [14]. Т. В. Майорова під інвестиційним кредитом розуміє кредитний процес, що включає сукупність механізмів реалізації кредитних відносин в інвестиційній сфері [8]. У працях А. В. Герасименко комплексно досліджує інвестиційне кредитування, під яким розуміє, довготермінове кредитування інвестиційних цілей позичальника (боржника), зміст яких зазвичай виклав у формі інвестиційного проекту, переважно під майбутні доходи, очікувані від результатів реалізації цього проекту позичальником (боржником), за рахунок яких відбудеться повернення кредитних коштів [2]. Науковий доробок В. Ю. Катасонова, Д. С. Морозова та М. В. Петрова полягає в тому, що інвестиційне кредитування розкрито 3 призми проектного фінансування, яке розглядається 3 двох позицій [1]:

1) як надання цільового кредиту з метою реалізації інвестиційного задуму з обмеженим регресом або без регресу кредитора на позичальника: забезпеченням виключно виступають грошові надходження та активи, які виникають під час реалізації проекту;

2) як один із можливих варіантів нагромадження фінансових ресурсів та, у комплексі з іншими, направлення на реалізацію інвестиційного проекту.

Водночас, розподіляючи фінансові ризики, що пов'язані із впровадженням інвестиційного задуму [4], Б. Пшик виявив, що інвестиційний кредит - це сукупність економічних відносин, що виникають між кредиторами та позичальниками з приводу задоволення тимчасових потреб у коштах для реалізації інвестиційних цілей [9]. Так, І. В. Іванець і Г. Ю. Жолнерчик, на основі дослідження думок вітчизняних та зарубіжних вчених, все ж вважають, що банківський інвестиційний кредит - це сукупність механізмів реалізації кредитних відносин в інвестиційній сфері, який є джерелом середньо- та довготермінових ресурсів для підприємства, на основі загальноекономічних та специфічних принципів кредитування [3]. Водночас, практично відсутні розробки вітчизняних та зарубіжних вчених щодо узагальнення і вдосконалення шляхів активізації банківського інвестиційного кредитування реального сектору економіки України.

Об'єкт дослідження - теоретико-методологічні та науково-прикладні засади банківського інвестиційного кредитування.

Предмет дослідження - шляхи вдосконалення банківського інвестиційного кредитування в сучасних умовах кредитування.

Мета дослідження - розробити пропозицій щодо активізації банківського інвестиційного кредитування реального сектору економіки.

Для досягнення поставленої мети необхідно виконати такі основні завдання дослідження:

- дослідити сутність та принципи організації банківського інвестиційного кредитування;

- розробити систему надання та погашення банківського інвестиційного кредитування реального сектору економіки;

- вдосконалити методику залучення прямих іноземних інвестицій та менеджменту в діяльності комерційних банків 3 питань управління кредитно-інвестиційним портфелем.

Результати дослідження. Банківське інвестиційне кредитування об'єднує в собі поняття кредиту й інвестицій. Для розгляду його теоретико-методологічних особливостей необхідно розкрити сутність інвестиції. Інвестиції в зарубіжній економічній літературі розглядають 3 двох сторін: ресурсів (власного капіталу) i вкладень (витрат). Такий підхід представлений в наукових працях Дж. М. Кейнса, на думку якого інвестиціїце частина доходу за певний період, яку не було використано для споживання, поточний приріст цінностей капітального майна внаслідок продуктивної діяльності цього періоду. Це визначення, яке не є досконалим, відрізняє досить чітке виділення двох сторін інвестицій: ресурсів (закумульованих з метою накопичення доходу) і вкладень (використання ресурсів), що забезпечують приріст капітальних активів [14].

Участь банків в інвестиційному процесі в загальному вигляді передбачає [6]:

- мобілізацію та перерозподіл банками коштів на інвестиційні цілі;

- надання кредитів інвестиційного характеру;

- вкладення коштів у цінні папери, паї, пайові участі (як за рахунок банку, так і за дорученням клієнта) [12].

Саме банківські інвестиційні кредити мають порівняно достатню дохідність за високих ризиків і низької ліквідності. Ці чинники є вирішальними в умовах нестабільності економіки, збільшуючи ризик неплатежів 3 інвестиційного кредиту i неможливість повернення коштів порівняно з державними цінними паперами.

Отже, банківське інвестиційне кредитування - це довготермінова послуга, яка доступна підприємцям, фізичним і юридичним особам, котрі бажають не просто розвивати свій бізнес, але які мають різні ідеї з удосконалення або відкриття нового напряму у своїй господарській діяльності [10].

3 метою активізації інвестиційного процесу, у вітчизняній та зарубіжній літературі виділяють такі принципи організації банківського інвестиційного кредитування [11]:

- розмежування функцій і відповідальності між кредитним та інвестиційним структурними підрозділами банку, створення проектних i матричних організаційних структур, що сприятиме оптимізації взаємовідносин між банком i клієнтами в інвестиційній сфері, закріпленню обов'язків 3 експертизи інвестиційних проектів за конкретними підроз- 
ділами (управліннями, відділами), гармонізації їх функцій, а також забезпеченню організації системи внутрішнього контролю у банку;

- розподіл процедури організації інвестиційного кредитування на різних стадіях, що дає змогу оптимізувати процес надання і погашення інвестиційного кредиту, встановити відповідність стадіям життєвого циклу інвестиційного проекту, що реалізовується суб'єктом господарювання;

- уніфікація процедури надання інвестиційного кредиту в усіх банках України, зумовлена необхідністю формування для підприємств, котрі розробляють інвестиційні проекти, чітких критеріїв, що визначають умови кредитування;

- пріоритетність інноваційних кредитних проектів, що зумовлена необхідністю технічної і технологічної модернізації та оновлення усіх галузей національної економіки і реалізовується у рамках інтерпретації рівня інноваційності під час оцінювання кредитоспроможності позичальників;

- системність аналізу та оцінки інвестиційної кредитоспроможності, що дає змогу узагальнити характеристику позичальника як щодо можливості ефективної реалізації проекту, генерування грошового припливу, так і щодо оцінки поточного фінансового стану і перспектив збереження фінан- сової сталості під час реалізації інвестиційного проекту в довготерміновому періоді;

- ефективність інвестиційного кредитування для банку і позичальників, що забезпечує узгодження інтересів і однакову зацікавленість сторін кредитної угоди в успішній реалізації інвестиційного проекту;

- формування ресурсної бази інвестиційного кредитування, тобто пріоритетність залучення стійких довготермінових пасивів, непов'язаних іноземних кредитних ресурсів, що забезпечує для банків зниження ризику ліквідності, створює сприятливі умови для оптимізації термінів і умов інвестиційного кредитування [4].

Реалізація цих принципів дасть змогу забезпечити створення належних умов для управління кредитним ризиком, а також застосування належної процедури надання інвестиційних кредитів відповідно до рекомендацій Базельського комітету з банківського нагляду [15].

Вивчення процедури надання інвестиційного кредиту, яка склалася на практиці вітчизняних банків, дає змогу встановити відповідність стадій кредитного процесу стадіям життєвого циклу інвестиційного проекту (рис. 1).

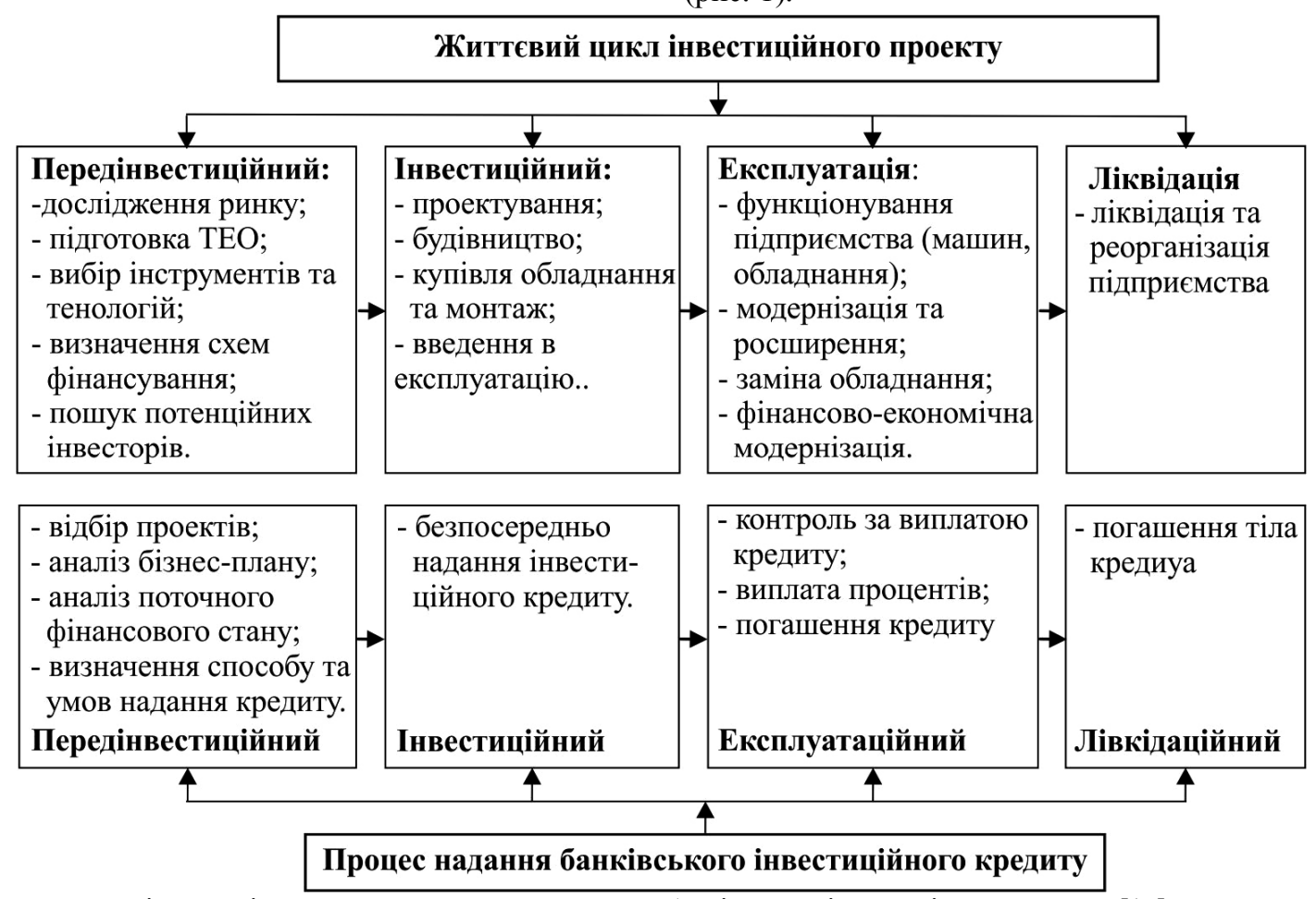

Рис. 1. Життєвий цикл інвестиційного проекту та процес надання банківського інвестиційного кредиту [15]

Оскільки період кредитування менший від терміну здійснення інвестиційного проекту, то надання кредитних ресурсів можна здійснювати на інвестиційній і (чи) на експлуатаційній стадіях його життєвого циклу, а повернення інвестиційного кредиту - на експлуатаційній стадії.

Разом із розвитком інвестиційного кредитування варто зазначити перспективність венчурного фінансування високоризикових інноваційних проектів як щодо охоплення усіх стадій інноваційного циклу (за винятком початкового етапу фундаментальних досліджень генерування нової ідеї), так і щодо можливості акумуляції венчурного капіталу за рахунок різних джерел, зокрема, доходів від приватизації, ресурсів банків, засобів різних фондів, нерезидентів. Венчурне фінансування як найбільш адекватне джерело інноваційного підприємництва, у специфічних умовах розвитку реально- го сектору економіки України, виділяють у своїх дослідженнях О. Д. Вовчак, Л. Г. Кльоба, С. В. Леонов та ін.

Достатнє задоволення потреб клієнтів у позикових коштах для фінансування інвестиційної діяльності, а також зниження банківських ризиків можливе лише на основі встановлення стійкого взаємозв'язку між кредитними інвестиційними операціями й операціями 3 формування ресурсної бази банку (рис. 2).

Інвестиційні кредити банків, з одного боку, можуть бути безпосередньо фінансовою складовою в інноваційному процесі (інвестиційно-інноваційні кредити), 3 іншого боку, кредитування інвестицій без інновацій, іпотечне кредитування, кредитування на розвиток бізнесу можуть сприяти посиленню потреби підприємств у розробці та впровадженні нововведень, які будуть створювати умови для залучення висококваліфікованих науково-технічних кадрів (сприяти інноваціям). 


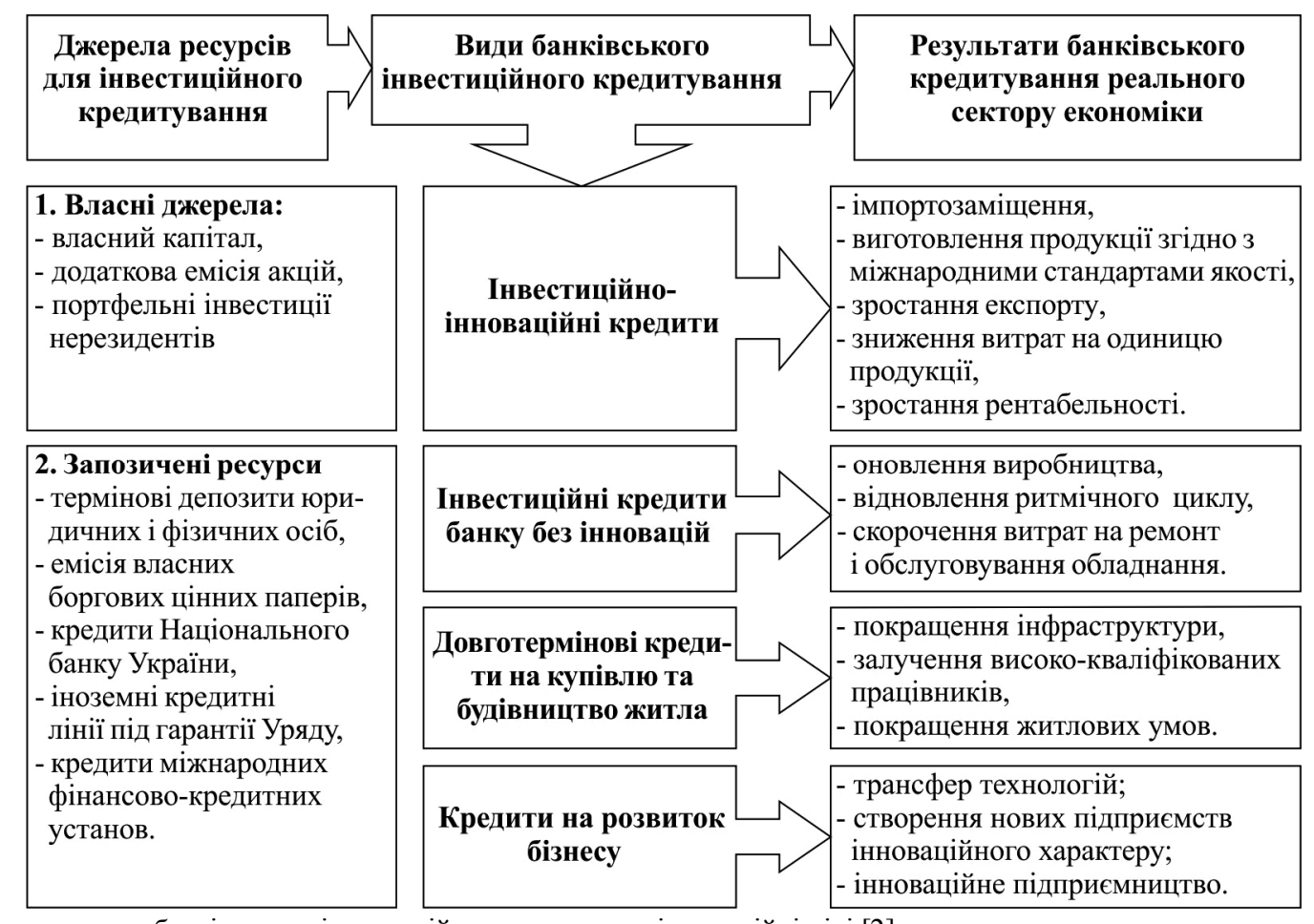

Рис. 2. Система надання банківського інвестиційного кредиту на інноваційні цілі [2]

Отож, вдосконалення системи надання та погашення банківського інвестиційного кредитування реального сектору економіки повинне містити два взаємопов'язані аспекти:

• вдосконалення оцінки інвестиційної кредитоспроможності, що визначає принципову можливість і умови надання кредиту, виходячи з рівня інноваційності й ефективності інвестиційного проекту, а також поточного фінансового стану потенційного позичальника;

- формування уніфікованого механізму визначення рівня процентної ставки, що дає змогу банку забезпечити покриття витрат із формування ресурсної бази інвестиційного кредитування, покриття ризиків, а також необхідний рівень перевищення доходів над витратами 3 цього виду діяльності, що допомагає підприємству реалізувати проект і забезпечити, відповідно до з дохідності банку, рівень ефективності [5].

Подібний підхід дасть змогу забезпечити компроміс інтересів банків і підприємств реального сектору економіки, які реалізовують державно і суспільно значущі проекти 3 високим рівнем інноваційності, посилити роль українських банків у забезпеченні інноваційного розвитку економіки, ефективному перерозподілі ресурсів 3 метою модернізації і технічного переоснащення галузей реального сектору економіки.

Потреба забезпечення стійкості й об'єднання зусиль у складній економічній ситуації стала важливою, але не єдиною обставиною посилення взаємодії фінансових структур. Рішення проблем перспективного розміщення активів унаслідок скорочення можливостей використання спекулятивних фінансових інструментів визначає вибір надійних і максимально контрольованих способів вкладення, якими і виступає інвестування у фінансовий бізнес. Водночас, інтеграція фінансових структур є однією з найважливіших передумов здійснення інвестицій в реальний сектор економіки, оскільки на базі малопотужних банків забезпечити масштабне інвестування виробництва не вдасться навіть за створення максимально сприятливих умов [7].
3 метою забезпечення необхідної пропорційності в кредитній системі України, варто розподілити ризики від інвестиційного кредитування шляхом створення спеціалізованих банків, а також розвивати інших фінансових посередників і створювати венчурні фонди.

Для забезпечення формування інноваційної інфраструктури національної економіки доцільно створити за рахунок власних коштів банків дочірніх венчурних організацій, а також фінансування їх діяльності, пов'язаної $з$ набуттям майнових прав на результати наукових досліджень і виконаних науково-технічних робіт як інвестора (придбання цінних паперів). Повніша взаємодія банків і суб'єктів інноваційної інфраструктури дасть змогу перерозподіляти грошові кошти в інноваційний сектор.

Висновки. Отже, можна зробити такі висновки про пріоритети банківського інвестиційного кредитування 3 метою розвитку реального сектору економіки:

- держава відіграє провідну роль у визначенні пріоритетів інвестиційного кредитування шляхом створення економічних стимулів для фінансування банками стратегічно важливих секторів національної економіки як кредитування розвитку реального сектору, малого бізнесу та соціально важливих cфep;

- основними напрямами розвитку інвестиційного кредитування реального сектору економіки є фінансування стратегічно важливих галузей промисловості України, які виступають фундаментальними галузями промисловості, зокрема, розвиток сільського господарства, металургійної, гірничовидобувної, легкої та інших галузей промисловості;

- також важливими пріоритетами банківського інвестиційного кредитування $є$ проведення модернізації та впровадження енергозберігаючих технологій, розвиток інфраструктури, надання фінансової підтримки малому та середньому бізнесу.

\section{References}

1. Dzjybljyk, O. V. (2014). Hroshovo-kredytne rehuliuvannia u mekhanizmi zabezpechennia makroekonomichnoi stabilizatsii $i$ efektyvnosti funktsionuvannia bankivskoi systemy Ukrainy. Ternopil: THEU, 530 p. [In Ukrainian]. 
2. Gerasymenko, A. V. (2015). Teoretychni zasady mehanizmu bankivskogo investytsijnogo kredytuvannja v Ukrajini. Uzhgorod University Scientific Bulletin, 2(46), 305-309. [In Ukrainian].

3. Ivanets, I. V., \& Zholnerchyk, G. Yu. (2018). Bankivske investytsiine kredytuvannia yak kliuchove dzherelo finansuvannia rozvytku realnoho sektoru ekonomiky. Finansovo-kredytna diialnist: problemy teorii ta praktyky, 1, 37-44. [In Ukrainian].

4. Katasonov, V. Yu., Morozov, D. S., \& Petrov, M. V. (2007). Proektnoe fynansyrovanye: myrovoi opit y perspektyvi. Moscow: Ankyl, 312 p. [In Russian].

5. Kloba, L. H. (2008). Investytsiina polityka bankiv v umovakh rynkovoi transformatsii ekonomiky. Rehionalna ekonomika, 1, 183-190. [In Ukrainian].

6. Lieonov, S. V. (2010). Investytsiinyi potentsial bankivskoi systemy: metodolohiia formuvannia ta vykorystannia. Abstract of doctoral dissertation for economic sciences. Sumy: Ukrainska akademiia bankivskoi spravy NBU, 32 p. [In Ukrainian].

7. Lutsiv, B. L. (2015). Banky v investuvanni ekonomichnoho rozvytku. Svit finansiv, 1, 151-161. [In Ukrainian].

8. Maiorova, T. V. (1997). Dovhostrokove kredytuvannia investytsiinykh proektiv. Finansy Ukrainy, 5, 48-51. [In Ukrainian].
9. Pshyk, B. I. (2005). Investytsiine kredytuvannia. Lviv: LBI NBU, 292 p. [In Ukrainian].

10. Pshyk, B. I., \& Pechenko, O. O. (2014). Aktualni problemy rozvytku bankivskoi investytsiinoi diialnosti v Ukraini. Finansovo-kredytna diialnist: problemy teorii ta praktyky, 2, 24-32. [In Ukrainian].

11. Stepanenko, A., \& Chamara, I. (2011). Sut intehratsii natsionalnoi bankivskoi systemy z realnym sektorom ekonomiky ta formy yii realizatsii. Visnyk $N B U, 3$, 7-12. [In Ukrainian].

12. Urvantseva, S. V. (2014). Sutnist ta znachennia investytsiinoho kredytu u suchasnykh umovakh hospodariuvannia. Molodyi vchenyi, 9, 65-69. [In Ukrainian].

13. Vovchak, O. D., \& Myskiv, G. V. (2015). Kredytni resursy subjektiv kredytnogo rynru: teoretyko-metodologichni pidhody. Bulletin of the National Bank of Ukraine, 3, 35-39. [In Ukrainian].

14. Vovchak, O. D., \& Rushchyshyn, N. M. (2016). Investytsijnyj menedzhment. Lviv: LTEU, 354 p. [In Ukrainian].

15. Vozhzhov, A., \& Popova, N. (2003). Investytsijne kredytuvannja komertsijnyh bankiv: zmist i vymogy do formuvannja resursnoji bazy. Bankivska sprava, 3, 73-79. [In Ukrainian].

V.A. Sydorenko

Kyiv National University of Trade and Economics, Kyiv, Ukraine

\section{WAYS OF ACTIVIZATION THE BANK INVESTMENT CREDITING FOR THE REAL ECONOMY}

The theoretical, methodological and structural features of the essence of bank investment crediting, which combines the concepts of investment and credit, are investigated. It is established that the participation of banks in the investment process involves granting investment credits for a long period, as well as investing in securities, units, and unit shares both at the banks and on behalf of the client. As a result of the study of the essence of bank investment crediting as a long-term service to its creditors, who want not only to develop their business, but who have different ideas for improving or opening a new direction in their business activities, the principles of organization of investment crediting by bank are highlighted. The procedure of granting an investment credit, which has been developed in practice of domestic banks, has allowed studying the conformity of the stages of the credit process with the stages of the life cycle of the investment project. The perspective of venture financing of high-risk innovation projects is characterized both in terms of coverage of all stages of the innovation cycle and in terms of the possibility of accumulating venture capital from various sources including privatization proceeds, bank resources, funds of different financial institutions, non-residents. It has been hypothesized that bank investment credits, on the one hand, are a mandatory financial component in the innovation process, and on the other hand, investment crediting without innovation, mortgage crediting, business development crediting can contribute to an increased need for enterprises to develop and implement innovations, which will create the conditions for attracting highly qualified scientific and technical staff (foster innovation). The system of granting and repayment of bank investment crediting to the real sector of economy has been improved, which should include two following interrelated aspects: estimation of investment solvency, as well as the mechanism of determining the level of interest rate on investment credit.

Keywords: investments; bank investment credit; investment project; innovations. 